
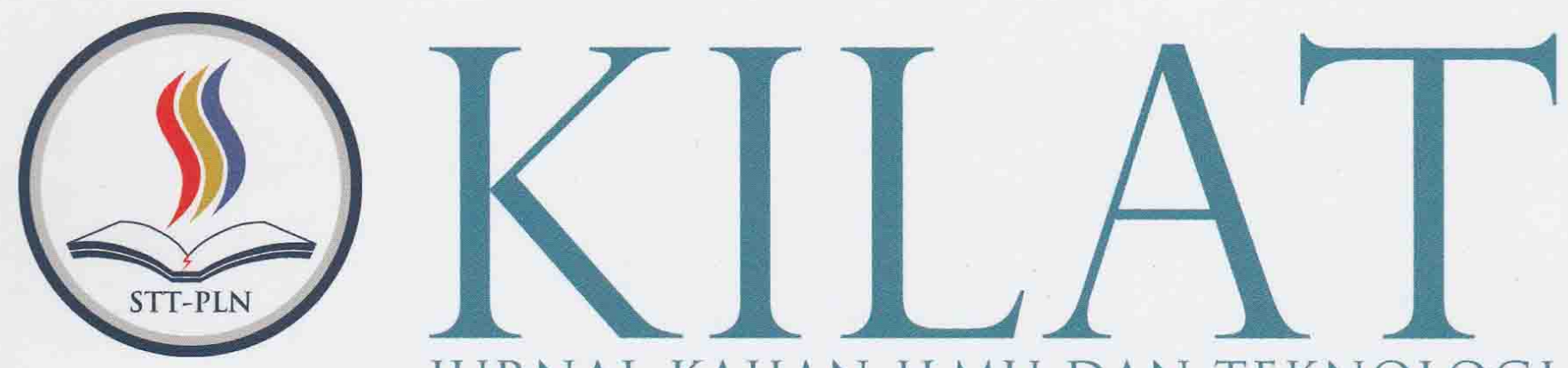
JURNAL KAJIAN ILMU DAN TEKNOLOGI

Dine Tiara Kusuma:

M. Yoga Distra Sudirman: Yessy Fitriani

Emillia; Yuliansyah

Rosida Nur Aziza; Dhzillan Dzhalila

Ranti Hidayawanti

Dewi Arianti Wulandari; Hendra Jatnika; Yudhy S. Purwanto

Rr. Mekar Ageng Kinasti; Endah Lestari; Devita Mayasari

Faisal Piliang

Mauludi Manfaluthy

Pauzi Hasan; Peby Wahyu Purnawan

Rahmi Amir: Baginda Oloan Lubis

Sabar Hanadwiputra; Subandri

Ndaru Ruseno; Satria
PENDEKATAN METODE ALTMAN Z-SCORE DALAM PENENTUAN INSENTIF BONUS PEGAWAI

METODE YURIDIS PENGELOLAAN SAMPAH RUMAH TANGGA DAN SAMPAH SEJENIS DI STT-PLN

METODE KUANTITATIF DENGAN PENDEKATAN KLASIK PADA APLIKASI ANALISIS BUTIR SOAL SEBAGAI MEDIA EVALUASI PENENTUAN SOAL YANG BERKUALITAS

UPAYA TERTIB LISTRIK TERHADAP INSTALATIR KABEL DI DAERAH PADAT PENDUDUK (STUDY KASUS KEC. TAMBORA)

RANCANG BANGUN APLIKASI CLUSTERING DATA MINING MENGGUNAKAN METODE K-MEANS DAN K-MODES

POTENSI PEMANFAATAN LIMBAH PEMBAKARAN BATUBARA (BOTTOM ASH) PADA PLTU SEBAGAI MEDIA TANAM DALAM UPAYA MENGURANGI PENCEMARAN LINGKUNGAN

PEMILIHAN PERANGKAT LUNAK PEMINDAHAN BERKAS DALAM MENINGKATKAN PEMANFAATAN TELEPON PINTAR

PEMANFAATAN RADIASI ENERGI TEGANGAN 150 KV UNTUK LAMPU LED PENERANGAN JALAN

KAJIAN PERBANDINGAN PERFORMANSI ROUTING PROTOCOL RIPNG, OSPFV3 DAN EIGRPVG PADA JARINGAN IPV6

PERANCANGAN PROGRAM PENGELOLAAN DATA KEUANGAN PASIEN RAWAT JALAN BPJS PADA RUMAH SAKIT GRAHA JUANDA BEKASI

ANALISA DAN IMPLEMENTASI VTP DENGAN ETHERCHANNEL TYPE LACP

PENGEMBANGAN RANCANG BANGUN SISTEM KESISWAAN DENGAN MENGGUNAKAN FRAMEWORK MVC

(MODEL VIEW CONTROLLER)

\begin{tabular}{|l|l|l|l|l|l|}
\hline KILAT & VOL.7 & NO.1 & HAL. 1 - 90 & APRIL 2018 & ISSN 2089 - 1245 \\
\hline
\end{tabular}




\title{
PERANCANGAN PROGRAM PENGELOLAAN DATA KEUANGAN PASIEN RAWAT JALAN BPJS PADA RUMAH SAKIT GRAHA JUANDA BEKASI
}

\author{
Rahmi Amir ${ }^{1}$; Baginda Oloan Lubis ${ }^{2}$ \\ ${ }^{1}$ Manajemen Informatika, AMIK BSI BEKASI \\ Jalan Cut Mutia Raya No.88, Margahayu, Bekasi Timur, Kota Bks, Jawa Barat 17113 \\ Email: rahmiamir95@gmail.com \\ ${ }^{2}$ Manajemen Informatika, AMIK BSI JAKARTA \\ Jl. Kamal Raya No.18, Cengkareng Barat, Cengkareng, Daerah Khusus Ibukota Jakarta 11730 \\ Email: baginda.bio@bsi.ac.id
}

\begin{abstract}
In today's era of globalization, information technology is speeding up. The computer is a device that was created to facilitate human work, while achieving good progress in the manufacture of hardware and software. Graha Juanda Hospital is a service business engaged in the field of health services. BPJS outpatient financial system that is done still manually from the calculation, data processing until the making of the report so it is possible at the time penginputan data error occurred in the recording or less accurate in the report made and delays in search data required. by using BPJS outpatient data management system that computerized BPJS outpatient financial data management will be more effective and efficient. In addition, the data stored neatly if at any time needed then the search data will be easier.
\end{abstract}

Keywords: Program, Patient Outpatient BPJS

\section{Abstrak}

Dalam era globalisasi sekarang ini, teknologi informasi melaju dengan cepatnya. Adapun komputer yang merupakan peralatan yang diciptakan untuk mempermudah pekerjaan manusia, saat mencapai kemajuan baik di dalam pembuatan hardware maupun software. Rumah Sakit Graha Juanda merupakan suatu usaha jasa yang bergerak di bidang pelayanan jasa kesehatan. Sistem keuangan pasien rawat jalan BPJS yang dilakukan masih secara manual dari perhitungan, pengolahan data sampai pembuatan laporan sehingga memungkinkan pada saat penginputan data terjadi kesalahan dalam pencatatan atau kurang akurat dalam laporan yang dibuat dan keterlambatan dalam pencarian data-data yang diperlukan. dengan menggunakan sistem pengelolaan data keuangan pasien rawat jalan BPJS yang terkomputerisasi pengelolaan data keuangan pasien rawat jalan BPJS akan lebih efektif dan efisien. Selain itu, data-data tersimpan rapi apabila sewaktu-waktu dibutuhkan maka pencarian data akan lebih mudah.

Kata Kunci: Program, Pasien Rawat Jalan BPJS

\section{PENDAHULUAN}

Rumah Sakit Graha Juanda merupakan salah satu Rumah Sakit di Kota Bekasi yang tugas dan fungsinya memberikan suatu pelayanan di bidang kesehatan terhadap masyarakat Bekasi dan sekitarnya. Sebagai instansi pelayanan umum, Rumah Sakit juga membutuhkan keberadaan suatu sistem informasi yang akurat dan handal, serta cukup memadai untuk meningkatkan pelayanannya kepada para pasien serta lingkungan yang terkait lainnya. Lingkungan terkait yang dimaksud adalah bagian informasi, bagian keuangan, dan bagian laboratorium. Dengan lingkup pelayanan yang begitu luas, tentunya banyak sekali permasalahan kompleks yang terjadi dalam proses pelayanan di Rumah Sakit. Untuk itu sangat diperlukan suatu pemikiran mengenai langkah-langkah pengembangan sistem yang telah digunakan sebelumnya dengan sistem baru yang memanfaatkan teknologi komputer sebagai alat bantu dalam menyelesaikan tugas-tugas, sehingga setiap pekerjaan dapat diselesaikan secara efisien dan efektif.

"Sistem komputerisasi telah menjadi kebutuhan utama bahkan terpenting untuk menjaga keamanan data, keakuratan yang lebih tinggi, serta kecepatan kinerja lembaga dalam rangka memenuhi kebutuhan bertransaksi”.(Lubis, 2016)

"Dengan adanya Jaminan Kesehatan Nasional oleh BPJS Kesehatan bertujuan untuk memberikan perlindungan kesehatan agar setiap peserta memperoleh manfaat pemeliharaan kesehatan", (Arini, 2015) sehingga diperlukan pengelolaan data yang dilakukan pada Rumah Sakit Graha Juanda agar pada saat pelaporannya sesuai dengan yang diharapkan oleh pihak BPJS.

Dalam penelitian ini masalah pengelolaan data pasien rawat jalan BPJS sampai pencetakan laporan pada Rumah Sakit Graha Juanda dimulai dari proses penyiapan data master pasien, data master user, data master spesialis, data master dokter, data master diagnosa hingga proses transaksi meliputi kunjungan pasien, data verifikasi, 
kwitansi sampai pencetakan kwitansi, laporan data pasien, laporan data user, laporan data dokter, laporan data diagnosa, laporan spesialis, laporan kunjungan pasien, laporan detail kunjungan pasien, dan laporan data verifikasi semuanya masih dilakukan dengan manual sehingga membutuhkan peroses yang lama. Untuk itu perlu dirancang suatu program pengelolaan data keuangan pasien rawat jalan BPJS dengan menggunakan metode pengembangan sistem pemodelan SDLC (System Development Life Cycle) yaitu Model Waterfall.

\section{METODE PENELITIAN}

\subsection{Pengumpulan Data}

a. Pengamatan Langsung (Observation), Dalam metode observasi ini peneliti melakukan pengamatan langsung ke Rumah Sakit Graha Juanda secara berkala untuk memperoleh informasi yang berhubungan masalah yang dibahas. Informasi yang didapat seperti data pasien, data dokter dan data lainnya didapat dari formulir data pasien, kartu pasien, formulir data doker dan formulir data obat beserta laporan yang ada pada Rumah Sakit Graha Juanda.

b. Wawancara (Interview), Tanya jawab secara langsung kepada staff Bagian Keuangan Rumah Sakit Graha Juanda dan kepada staff dilingkungan Rumah Sakit Graha Juanda untuk mendapatkan informasi yang berkaitan dengan masalah yang di teliti. Wawancara dilakukan dengan mencari kebutuhan user dalam hal ini staff Rumah Sakit Graha Juanda dan staff dilingkungan Rumah Sakit Graha Juanda yang nantinya akan menjadi user dalam pembangunan sistem ini.

c. Studi Pustaka (Library research), Mencari informasi sebagai sumber referensi terhadap suatu masalah dengan buku-buku yang sumber data yang lain seperti artikel ilmiah dan referensi terpercaya lainnya untuk penunjang penelitian ini. Dari buku-buku dan sumber data yang lain penulis menemukan gambaran seperti apa nantinya pembangunan sistem yang akan dibangun.

\subsection{Metode Pengembangan Perangkat Lunak}

Metode yang digunakan pada pengembangan perangkat lunak ini menggunakan model Waterfall (Air terjun). Metode air terjun menyediakan pendekatan alur hidup perangkat lunak secara sekuensial atau terurut yang dimulai analisis, desain, pengodean, pengujian dan tahap pendukung (support). Model waterfall terbagi menjadi lima tahapan, yaitu: (Rosa,2013)

a. Analisis kebutuhan perangkat lunak

Pada tahap ini penulis menganalisa permasalahan yang terjadi dan kebutuhan perangkat lunak agar dapat dipahami seperti apa yang dibutuhkan oleh pengguna program. Proses ini dimulai dengan membuat gambaran apa yang dapat dilakukan oleh User dan Administrator. b. Desain

Setelah menganalisa kebutuhan perangkat lunak, penulis membuat desain menggunakan ERD (Entity Relationship Diagram), LRS (Logical Record Structured), HIPO (Hirarchy Input Process Output) dan Diagram Alir Program (Program Flowchart).

c. Pembuatan kode program

Pada tahap ini penulis membuat kode program sesuai dengan rancangan ERD (Entity Relationship Diagram), LRS (Logical Record Structured), HIPO (Hirarchy Input Process Output) dan Diagram Alir Program (Flowchart) yang sebelumnya telah dibuat. Aplikasi yang digunakan untuk membuat kode pemrograman menggunakan Microsoft Visual Basic 6.0 dan Crystal Reports sebagai software pendukungnya.

d. Pengujian

Pada tahap ini penulis melakukan percobaan dari program yang sudah dibuat, apakah setiap tools sudah berjalan dengan baik dan apakah program sudah sesuai dengan keinginan pemakai. Jika masih ada kesalahan dan kekurangan maka akan dilakukan perbaikan.

e. Pendukung (support) atau pemeliharaan (maintenance)

Pada tahap ini dilakukan perawatan atau maintenance pada program yang sudah dibuat secara berkala. Jika ada kerusakan pada program atau akan di tambahkan tools baru, maka akan segera dilakuakan perbaikan atau tindakan.

Analisis kebutuhan sistem dimulai dari proses penyiapan data master pasien, data master user, data master spesialis, data master dokter, data master diagnosa hingga proses transaksi yang meliputi kunjungan pasien, data verifikasi, kwitansi sampai pencetakan kwitansi, laporan data pasien, laporan data user, laporan data dokter, laporan data diagnosa, laporan spesialis, laporan kunjungan pasien, laporan detail kunjungan pasien dan laporan data verifikasi.

\subsection{Kebutuhan Administrator:}

a. Sistem dapat melakukan Login dengan cara memasukkan username dan password.

b. Sistem dapat melakukan pendataan pasien, yang meliputi pendataan pasien baru, pengubahan data pasien, dan penghapusan data pasien.

c. Sistem dapat melakukan pendataan dokter, yang meliputi pendataan dokter baru, pengubahan data dokter dan penghapusan data dokter.

d. Sistem dapat melakukan pendataan user, yang terdiri dari pendataan user baru, perubahan data user, serta penghapusan data user.

e. Sistem dapat melakukan pendataan diagnosa, yang meliputi pendataan diagnosa baru, pengubahan data dan penghapusan data diagnosa.

f. Sistem dapat melakukan pendataan spesialis, yang meliputi pendataan spesialis baru, 
pengubahan data dan penghapusan data spesialis.

g. Sistem dapat mengganti password dengan cara mengkonfirmasi password lama lalu memasukan password baru dan konfirmasi password baru.

h. Sistem dapat melakukan transaksi kunjungan pasien, yang berisi nomor rekam medis, data diagnosa pasien, data dokter dan biaya berobat pasien.

i. Sistem dapat melakukan data verifikasi.

j. Sistem dapat membuat serta mencetak kwitansi Claim BPJS.

k. Sistem dapat menampilkan serta mencetak laporan data pasien.

I. Sistem dapat menampilkan serta mencetak laporan data user.

m. Sistem dapat menampilkan serta mencetak laporan data dokter.

n. Sistem dapat menampilkan serta mencetak laporan data diagnosa.

o. Sistem dapat menampilkan serta mencetak laporan data spesialis.

p. Sistem dapat menampilkan serta mencetak laporan kunjungan pasien.

q. Sistem dapat menampilkan serta mencetak laporan data verifikasi.

r. Sistem dapat menampilkan serta mencetak laporan detail kunjungan pasien berdasarkan nomor rekam medis pasien.

s. Sistem dapat menggunakan Logout dan Backup Database otomatis setelah menggunakan aplikasi.

\subsection{Kebutuhan Bagian Keuangan}

a. Sistem dapat melakukan Login dengan cara memasukkan username dan password.

b. Sistem dapat melakukan pendataan pasien, yang meliputi pendataan pasien baru, pengubahan data pasien, dan penghapusan data pasien.

c. Sistem dapat melakukan pendataan dokter, yang meliputi pendataan dokter baru, pengubahan data dokter dan penghapusan data dokter.

d. Sistem dapat melakukan pendataan diagnosa, yang meliputi pendataan diagnosa baru, pengubahan data dan penghapusan data diagnosa.

e. Sistem dapat melakukan pendataan spesialis, yang meliputi pendataan spesialis baru, pengubahan data dan penghapusan data spesialis. f. Sistem dapat mengganti password dengan cara mengkonfirmasi password lama lalu memasukan password baru dan konfirmasi password baru.

g. Sistem dapat melakukan transaksi kunjungan pasien, yang berisi nomor rekam medis pasien, data diagnosa pasien, data dokter dan biaya berobat pasien.

h. Sistem dapat melakukan data verifikasi.

i. Sistem dapat membuat serta mencetak kwitansi Claim BPJS.

j. Sistem dapat menampilkan serta mencetak laporan data pasien.

k. Sistem dapat menampilkan serta mencetak laporan data dokter.

I. Sistem dapat menampilkan serta mencetak laporan data diagnosa.

m. Sistem dapat menampilkan serta mencetak laporan data spesialis.

n. Sistem dapat menampilkan serta mencetak laporan kunjungan pasien.

o. Sistem dapat menampilkan serta mencetak laporan detail kunjungan pasien berdasarkan nomor rekam medis pasien.

p. Sistem dapat menampilkan serta mencetak laporan data verifikasi.

q. Sistem dapat menggunakan Logout dan Backup Database otomatis setelah menggunakan aplikasi.

Berdasarkan kebutuhan sistem peneliti melakukan metode penelitian dengan menggunakan dua metode yaitu metode pengumpulan data dan pengembangan perangkat lunak.

\section{HASIL DAN PEMBAHASAN}

\subsection{Desain}

a. Rancangan Entity Relationship Diagram (ERD)

"(Entity Relationship Digram) merupakan "sebuah diagram yang digunakan untuk merancang hubungan antar tabel-tabel dalam basis data". Berikut adalah simbol-simbol yang sering digunakan pada ERD untuk merancang tabel-tabel beserta relasinya dalam basis data (dalam buku ini dibahas sebagai dasar agar mudah dimengerti. (Shalahuddin,2010). Rancangan ERD dalam sistem yang akan dibangun dapat dilihat pada gambar berikut: 


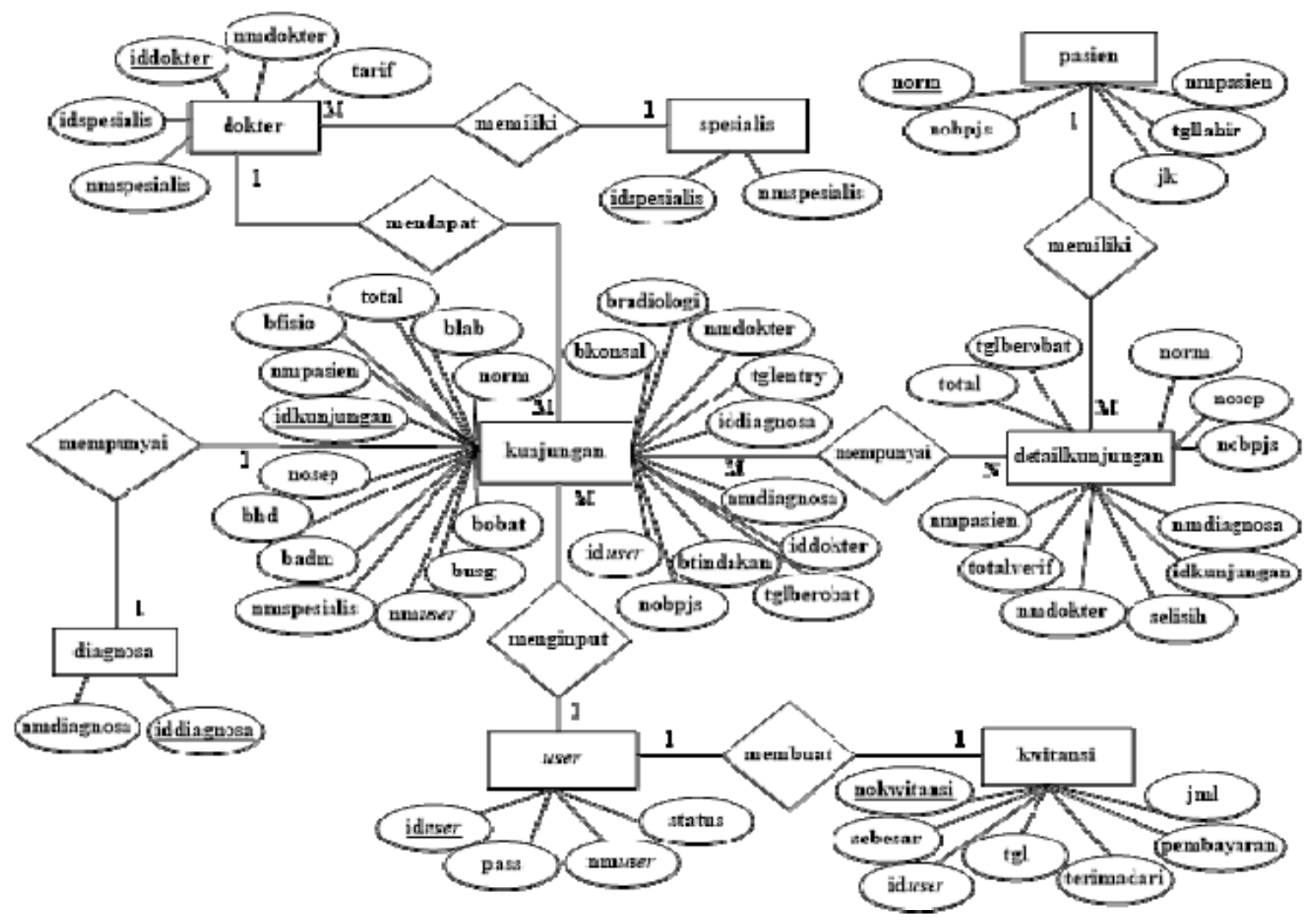

Gambar 1. Rancangan Entity Relationship Diagram (ERD)

b. Rancangan Logical Relational Structure (LRS)

"LRS merupakan hasil dari pemodelan Entity

Relational Ship (ER) beserta atributnya sehingga bisa terlihat hubungan-hubungan antar entitas". (Rahmayu,2015)

Dalam pembuatan LRS terdapat 3 hal yang dapat mempengaruhi yaitu:

1. Jika tingkat hubungan (cardinality) satu pada satu (One-to-One), maka di gabungkan dengan entitas yang lebih kuat (strong entity), atau digabungkan dengan entitas yang memiliki atribut yang lebih sedikit.
2. Jika tingkat hubungan (cardinality) satu pada banyak (one-to-many), maka hubungan relasi atau digabungkan dengan entitas yang tingkat hubungannya banyak.

3. Jika tingkat hubungan (cardinality) banyak pada banyak (many-to-many), maka hubungan relasi tidak akan digabungkan dengan entitas manapun, melainkan menjadi sebuah LRS.

Berdasarkan ERD yang sudah dirancang kemudian ditrasfer menjadi LRS:

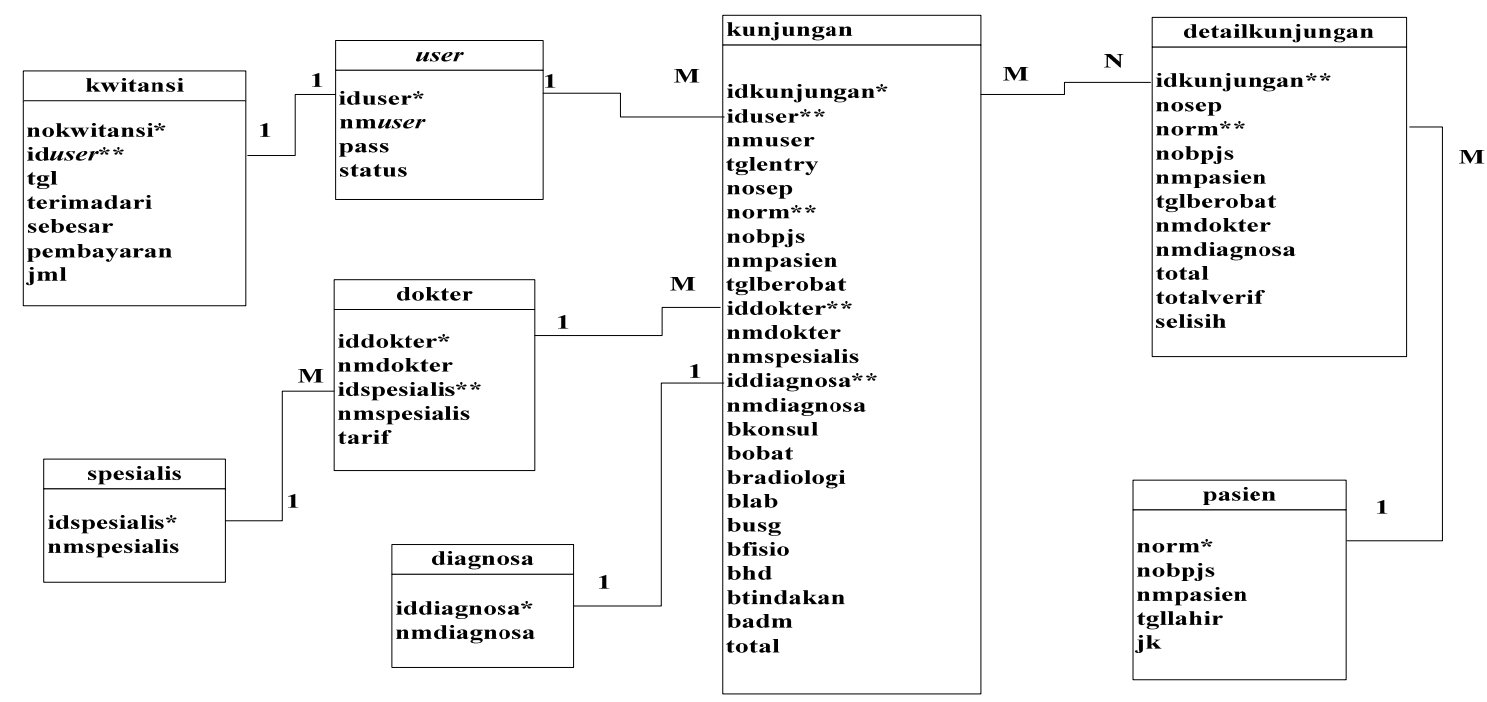

Gambar 2. Rancangan Logical Relational Structure (LRS) 
c. Spesifikasi File

Menjelaskan tentang file atau tabel yang terbentuk dari transformasi entity relationship diagram (ERD). File-file ini tersimpan pada $\mathrm{db}$ rsgj dengan parameter-parameter adalah sebagai berikut:

1. Spesifikasi File User

$\begin{array}{ll}\text { Nama File } & \text { : User } \\ \text { Akronim } & \text { : user } \\ \text { Fungsi } & \text { : Untuk menyimpan data } \\ & \text { user } \\ \text { Tipe File } & \text { : File Master } \\ \text { Organisasi File } & \text { : Index Sequential } \\ \text { Akses File } & \text { : Random Accsess File } \\ \text { Media } & \text { : Hard Disk } \\ \text { Panjang record } & : \text { C5 byte } \\ \text { Kunci Field } & : \text { iduser } \\ \text { Software } & : \text { Xampp }\end{array}$

Tabel 1. Spesifikasi File User

\begin{tabular}{|c|l|l|l|c|l|}
\hline No & $\begin{array}{c}\text { Elemen } \\
\text { Data }\end{array}$ & $\begin{array}{c}\text { Nama } \\
\text { Field }\end{array}$ & \multicolumn{1}{|c|}{ Tipe } & Panjang & Keterangan \\
\hline 1 & Id user & iduser & Char & 5 & Primary Key \\
\hline 2 & nama user & nmuser & Varchar & 30 & \\
\hline 3 & password & pass & Varchar & 15 & \\
\hline 4 & status & status & Varchar & 15 & \\
\hline
\end{tabular}

2. Spesifikasi File Dokter

$\begin{array}{ll}\text { Nama File } & \text { : Dokter } \\ \text { Akronim } & \text { : dokter } \\ \text { Fungsi } & \text { : Untuk menyimpan data } \\ & \text { dokter } \\ \text { Tipe File } & \text { : File Master } \\ \text { Organisasi File } & \text { : Index Sequential } \\ \text { Akses File } & \text { : Random Accsess File } \\ \text { Media } & \text { : Hard Disk } \\ \text { Panjang record } & : \text { T9 byte } \\ \text { Kunci Field } & \text { : iddokter } \\ \text { Software } & \text { : Xampp }\end{array}$

Tabel 2. Spesifikasi File Dokter

\begin{tabular}{|c|l|l|l|r|l|}
\hline No & $\begin{array}{c}\text { Elemen } \\
\text { Data }\end{array}$ & Nama Field & \multicolumn{1}{|c|}{ Tipe } & Panjang & Keterangan \\
\hline 1 & id dokter & iddokter & Char & 5 & Primary Key \\
\hline 2 & nama dokter & nmdokter & Varchar & 30 & \\
\hline 3 & id spesialis & idspesialis & Char & 3 & \\
\hline 4 & $\begin{array}{l}\text { nama } \\
\text { spesialis }\end{array}$ & nmspesialis & Varchar & 30 & \\
\hline 5 & tarif & tarif & int & 11 & \\
\hline
\end{tabular}

3. Spesifikasi File Pasien

$\begin{array}{ll}\text { Nama File } & \text { : Pasien } \\ \text { Akronim } & : \text { pasien } \\ \text { Fungsi } & : \text { Untuk menyimpan data } \\ \text { pasien } & \text { : File Master } \\ \text { Tipe File } & : \text { Index Sequential } \\ \text { Organisasi File } & \text { : Random Accsess File } \\ \text { Akses File } & \text { : Hard Disk } \\ \text { Media } & : 63 \text { byte } \\ \text { Panjang record } & : \text { norm } \\ \text { Kunci Field } & : \text { Xampp } \\ \text { Software } & \end{array}$

Tabel 3. Spesifikasi File Pasien

\begin{tabular}{|c|l|l|l|r|l|}
\hline No & \multicolumn{1}{|c|}{ Elemen Data } & $\begin{array}{c}\text { Nama } \\
\text { Field }\end{array}$ & \multicolumn{1}{|c|}{ Tipe } & Panjang & Keterangan \\
\hline 1 & $\begin{array}{l}\text { nomor rekam } \\
\text { medis }\end{array}$ & norm & Char & 8 & Primary Key \\
\hline 2 & nomor BPJS & nobpjs & Varchar & 15 & \\
\hline 3 & nama pasien & nmpasien & Varchar & 30 & \\
\hline 4 & tanggal lahir & tlglahir & date & 8 & \\
\hline 5 & jenis kelamin & jk & Varchar & 2 & \\
\hline
\end{tabular}

4. Spesifikasi File Diagnosa

$\begin{array}{ll}\text { Nama File } & \text { : Diagnosa } \\ \text { Akronim } & \text { : diagnosa } \\ \text { Fungsi } & : \text { Untuk menyimpan data } \\ \text { diagnosa } & \text { : File Master } \\ \text { Tipe File } & : \text { Index Sequential } \\ \text { Organisasi File } & \text { : Random Accsess File } \\ \text { Akses File } & : \text { Hard Disk } \\ \text { Media } & : \text { : } 33 \text { byte } \\ \text { Panjang record } & : \text { iddiagnosa } \\ \text { Field Kunci } & : \text { Xampp } \\ \text { Software } & \end{array}$

Tabel 4. Spesifikasi File Diagnosa

\begin{tabular}{|c|l|l|l|c|c|}
\hline No & Elemen Data & Nama Field & Tipe & Panjang & Keterangan \\
\hline 1 & id diagnosa & iddiagnosa & Char & 3 & Primary Key \\
\hline 2 & $\begin{array}{l}\text { nama } \\
\text { diagnosa }\end{array}$ & nmdiagnosa & Varchar & 30 & \\
\hline
\end{tabular}

5. Spesifikasi File Spesialis

$\begin{array}{ll}\text { Nama File } & \text { : Spesialis } \\ \text { Akronim } & \text { : spesialis } \\ \text { Fungsi } & : \text { Untuk menyimpan data } \\ \text { spesialis } & : \text { File Master } \\ \text { Tipe File } & : \text { Index Sequential } \\ \text { Organisasi File } & \text { : Random Accsess File } \\ \text { Akses File } & \text { : Hard Disk } \\ \text { Media } & : \text { : } 33 \text { byte } \\ \text { Panjang record } & : \text { idspesialis } \\ \text { Kunci Field } & : \text { Xampp } \\ \text { Software } & \end{array}$

Tabel 5. Spesifikasi File Spesialis

\begin{tabular}{|c|l|l|l|c|c|}
\hline No & Elemen Data & Nama Field & Tipe & Panjang & Keterangan \\
\hline 1 & id spesialis & idspesialis & Char & 3 & Primary Key \\
\hline 2 & nama spesialis & nmspesialis & Varchar & 30 & \\
\hline
\end{tabular}

6. Spesifikasi File Kunjungan

$\begin{array}{ll}\text { Nama File } & \text { : Kunjungan } \\ \text { Akronim } & \text { : kunjungan } \\ \text { Fungsi } & \text { : Untuk menyimpan data } \\ \text { kunjungan pasien } & \\ \text { Tipe File } & \text { : File Transaksi } \\ \text { Organisasi File } & : \text { Index Sequential } \\ \text { Akses File } & \text { : Random Accsess File } \\ \text { Media } & \text { : Hard Disk } \\ \text { Panjang record } & : \text { :337 byte } \\ \text { Kunci Field } & : \text { idkunjungan } \\ \text { Software } & : \text { Xampp }\end{array}$


Tabel 6. Spesifikasi File Kunjungan

\begin{tabular}{|c|l|l|l|c|l|}
\hline No & \multicolumn{1}{|c|}{ Elemen Data } & \multicolumn{1}{|c|}{ Nama Field } & \multicolumn{1}{|c|}{ Tipe } & Panjang & Keterangan \\
\hline 1 & id kunjungan & idkunjungan & Char & 10 & Primary Key \\
\hline 2 & id user & iduser & Char & 5 & \\
\hline 3 & nama user & nmuser & Varchar & 30 & \\
\hline 4 & tanggal entry & tglentry & Date & 8 & \\
\hline 5 & nomor SEP & nosep & Varchar & 15 & \\
\hline 6 & nomor rekam medis & norm & Char & 8 & \\
\hline 7 & nomor BPJS & nobpjs & Varchar & 15 & \\
\hline 8 & nama pasien & nmpasien & Varchar & 30 & \\
\hline 9 & tanggal berobat & tglberobat & Date & 8 & \\
\hline 10 & id dokter & iddokter & Char & 5 & \\
\hline 11 & nama dokter & nmdokter & Varchar & 30 & \\
\hline 12 & nama spesialis & nmspesialis & Varchar & 30 & \\
\hline 13 & id diagnosa & iddiagnosa & Char & 3 & \\
\hline 14 & nama diagnosa & nmdiagnosa & Varchar & 30 & \\
\hline 15 & biaya konsultasi & bkonsul & Int & 11 & \\
\hline 16 & biaya obat & bobat & Int & 11 & \\
\hline 17 & biaya radiologi & bradiologi & Int & 11 & \\
\hline 18 & biaya laboratorium & blab & Int & 11 & \\
\hline 19 & biaya usg & busg & Int & 11 & \\
\hline 20 & biaya fisioteraphy & bfisio & Int & 11 & \\
\hline 21 & biaya Hemodialisa & bhd & Int & 11 & \\
\hline 22 & biaya tindakan & btindakan & Int & 11 & \\
\hline 23 & biaya administrasi & badm & Int & 11 & \\
\hline 24 & total & total & Int & 11 & \\
\hline & & & & & \\
\hline
\end{tabular}

7. Spesifikasi File Detail Kunjungan

$\begin{array}{ll}\text { Nama File } & \text { : Detail Kunjungan } \\ \text { Akronim } & \text { : detailkunjungan } \\ \text { Fungsi } & : \text { Untuk menyimpan data } \\ \text { detail kunjungan pasien } & \text { : File Transaksi } \\ \text { Tipe File } & : \text { Index Sequential } \\ \text { Organisasi File } & \text { : Random Accsess File } \\ \text { Akses File } & : \text { Hard Disk } \\ \text { Media } & : \text { 179 byte } \\ \text { Panjang record } & :- \\ \text { Kunci Field } & : \text { Xampp } \\ \text { Software } & \end{array}$

Tabel 7. Spesifikasi File Detail Kunjungan

\begin{tabular}{|c|l|l|l|c|c|}
\hline No & \multicolumn{1}{|c|}{ Elemen Data } & Nama Field & \multicolumn{1}{|c|}{ Tipe } & Panjang & Keterangan \\
\hline 1 & id kunjungan & idkunjungan & Char & 10 & Primary Key \\
\hline 2 & nomor SEP & nosep & Varchar & 15 & \\
\hline 3 & nomor rekam medis & norm & Char & 8 & \\
\hline 4 & nomor BPJS & nobpjs & Varchar & 15 & \\
\hline 5 & nama pasien & nmpasien & Varchar & 30 & \\
\hline 6 & tanggal berobat & tglberobat & Date & 8 & \\
\hline 7 & nama dokter & nmdokter & Varchar & 30 & \\
\hline 8 & nama diagnosa & nmdiagnosa & Varchar & 30 & \\
\hline 9 & total & total & Int & 11 & \\
\hline 10 & total verifikasi & totalverif & Int & 11 & \\
\hline 11 & selisih & selisih & Int & 11 & \\
\hline
\end{tabular}

8. Spesifikasi File Kwitansi

$\begin{array}{ll}\text { Nama File } & \text { : Kwitansi } \\ \text { Akronim } & \text { : kwitansi } \\ \text { Fungsi } & \text { : Untuk menyimpan data } \\ \text { cetak kwitansi } & \\ \text { Tipe File } & \text { : File Transaksi } \\ \text { Organisasi File } & \text { : Index Sequential } \\ \text { Akses File } & \text { : Random Accsess File } \\ \text { Media } & \text { : Hard Disk } \\ \text { Panjang record } & \text { : 369 byte } \\ \text { Kunci Field } & \text { : nokwitansi } \\ \text { Software } & \text { : Xampp }\end{array}$

Tabel 8. Spesifikasi File Kwitansi

\begin{tabular}{|c|l|l|l|c|l|}
\hline No & Elemen Data & \multicolumn{1}{|c|}{ Nama Field } & Tipe & Panjang & Keterangan \\
\hline 1 & nomor kwitansi & nokwitansi & Char & 4 & Primary Key \\
\hline 2 & id user & iduser & Char & 5 & \\
\hline 3 & tanggal & tgl & Date & 8 & \\
\hline 4 & terima dari & terimadari & Varchar & 35 & \\
\hline 5 & sebesar & sebesar & Varchar & 290 & \\
\hline 6 & pembayaran & pembayaran & Varchar & 12 & \\
\hline 7 & jumlah & jml & Double & 15 & \\
\hline
\end{tabular}

d. Hierarchy plus Input Process Output (HIPO)

Spesifikasi program merupakan penjelasan mengenai instruksi-instruksi atau perintah yang ada dalam suatu program untuk mempermudah pemprosesan data. Berikut ini adalah gambaran tentang menu-menu yang ada pada program pengelolaan data keuangan di Rumah Sakit Graha Juanda dalam bentuk Hierarchy plus Input Process Output (HIPO). 


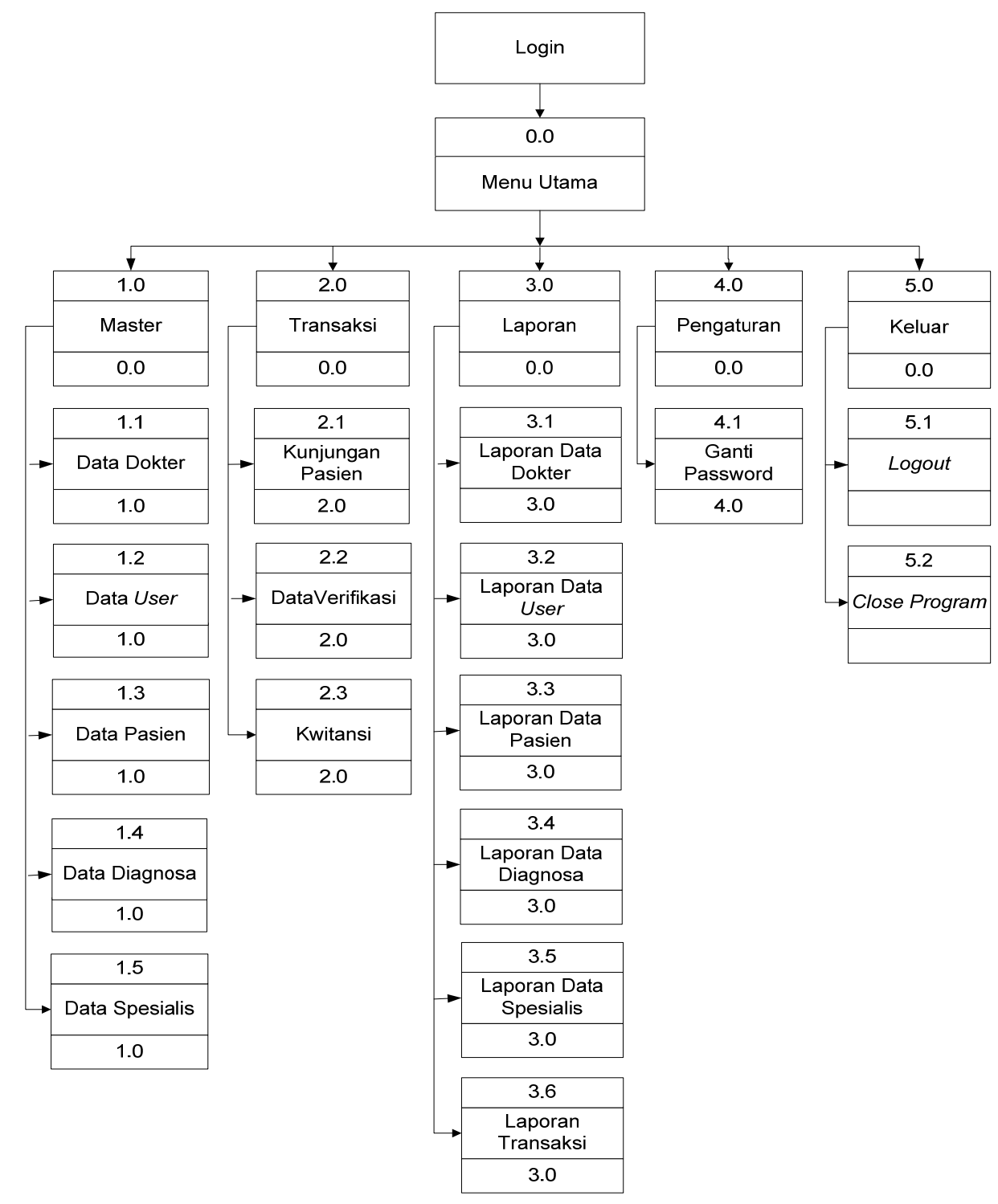

Gambar 3. Diagram Hierarchy plus Input Process Output (HIPO)

\section{e. Flowchart}

Bagan alir (flowchart) merupakan "kumpulan dari notasi diagram simbolik yang menunjukkan aliran data dan urutan operasi dalam sistem".( Mardi ,2014) Bagan alir (flowchart) merupakan metode teknik analisis yang dipergunakan untuk mendeskripsikan sejumlah aspek dari sistem informasi secara jelas, ringkas dan logis. Sebuah bagan alir akan representasikan grafikal pada suatu sistem yang menggambarkan terjadinya relasi fisik 1. Flowchart Menu Utama Admin antara entitas kuncinya. Auditor, analis sistem, perancang sistem, dan pemrogram, merupakan orang-orang yang paling mengenal notasi ini.

Algoritma program yang diekspresikan dengan suatu diagram atau bagan program sesuai dengan simbol-simbol dalam program flowchart. Berikut ini adalah flowchart program pengelolaan data keuangan pasien rawat jalan BPJS di Rumah Sakit Graha Juanda. 


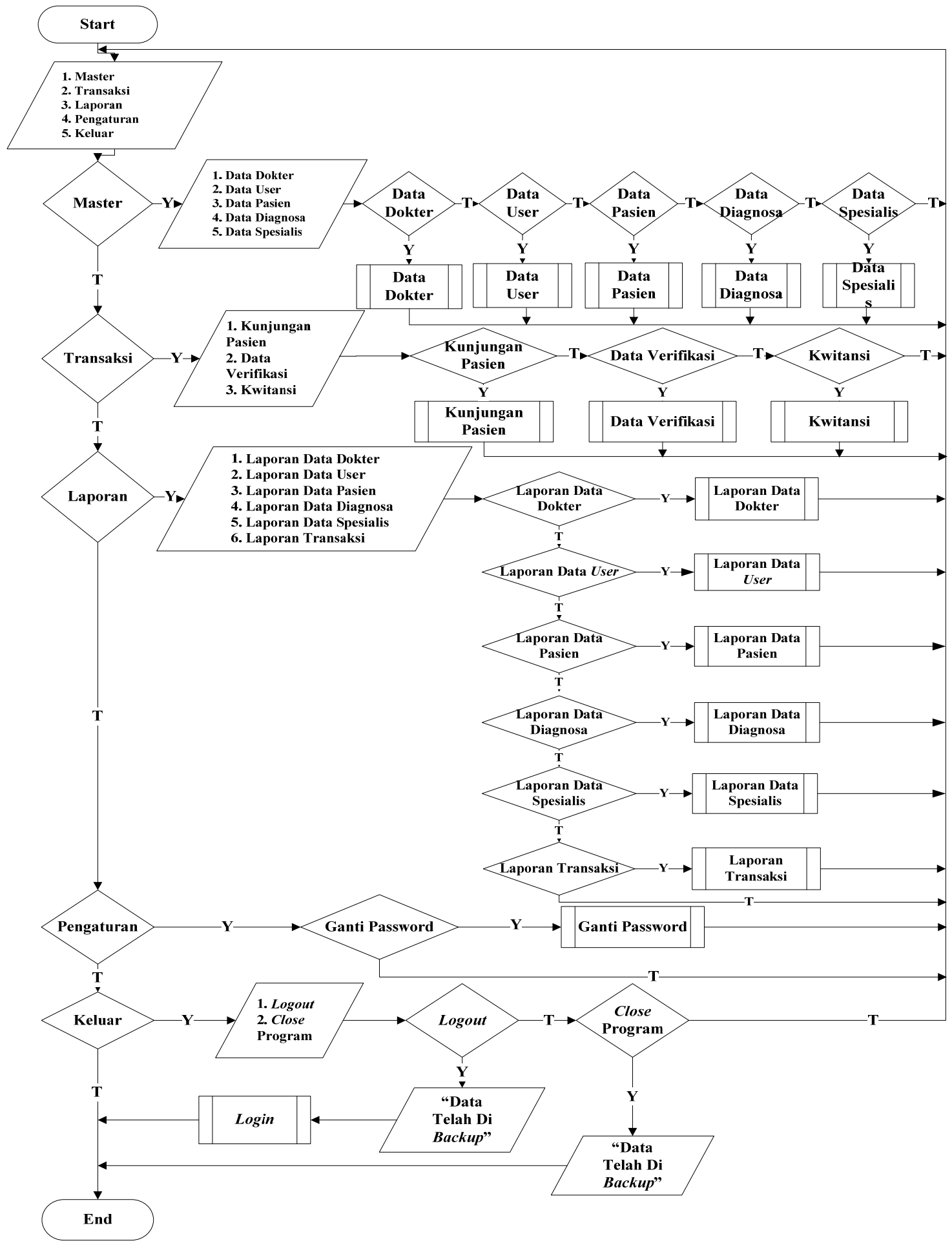

Gambar 4. Flowchart Utama Admin 


\section{Flowchart Menu Utama Bagian Keuangan}

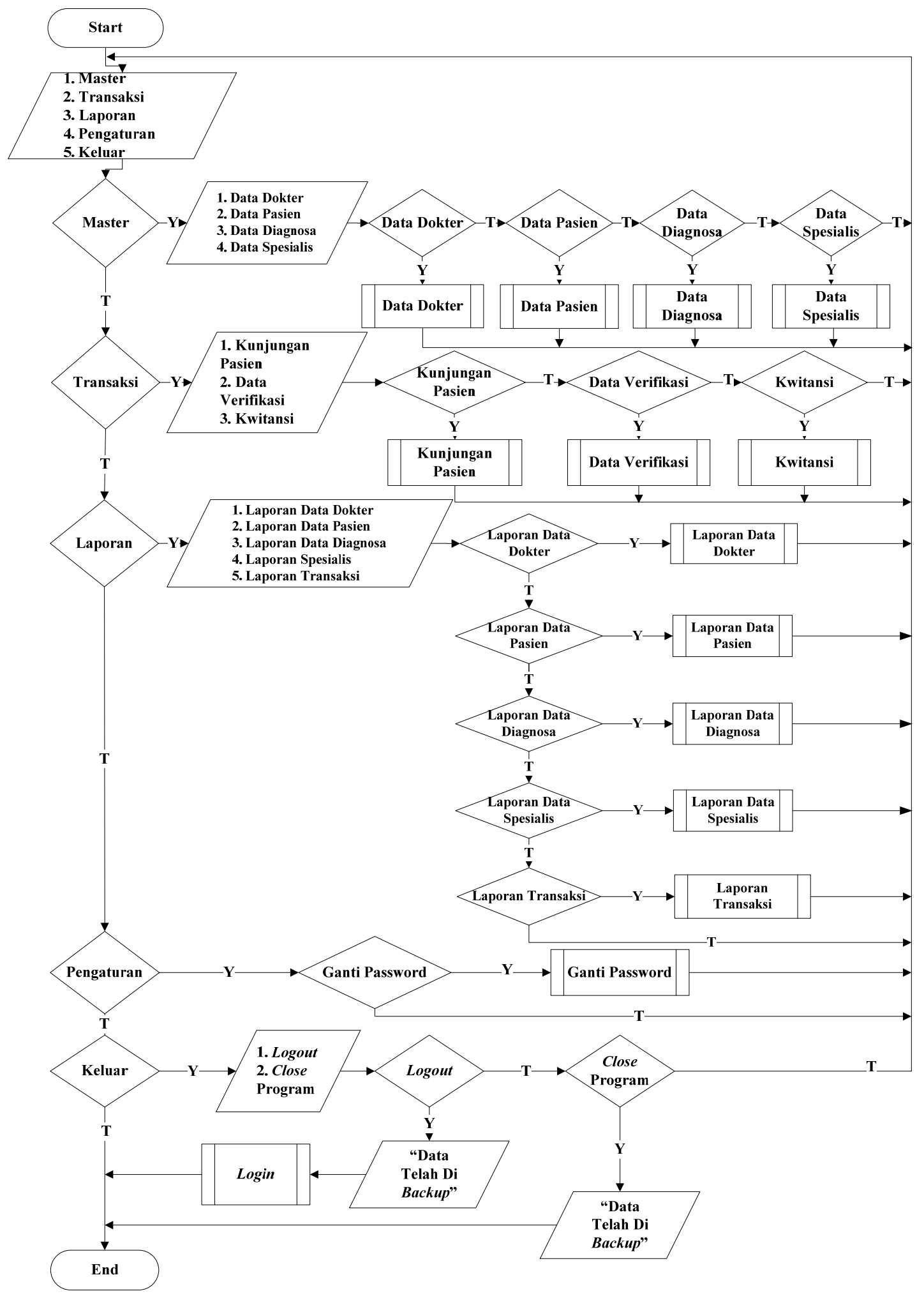

Gambar 5. Flowchart Utama Bagian Keuangan

\subsection{Pembuatan kode program}

Sesuai dengan rancangan ERD (Entity Relationship Diagram), LRS (Logical Record Structured), HIPO (Hirarchy Input Process Output) dan Diagram Alir Program (Flowchart) yang sebelumnya telah dibuat selanjutnya dilakukan pengkodean program, dimana yang selesaikan terlebih dahulu menu login selanjutnya menu-menu yang lain yang dibutuhkan dalam pebangunan aplikasi ini. 
a. Form Menu Login

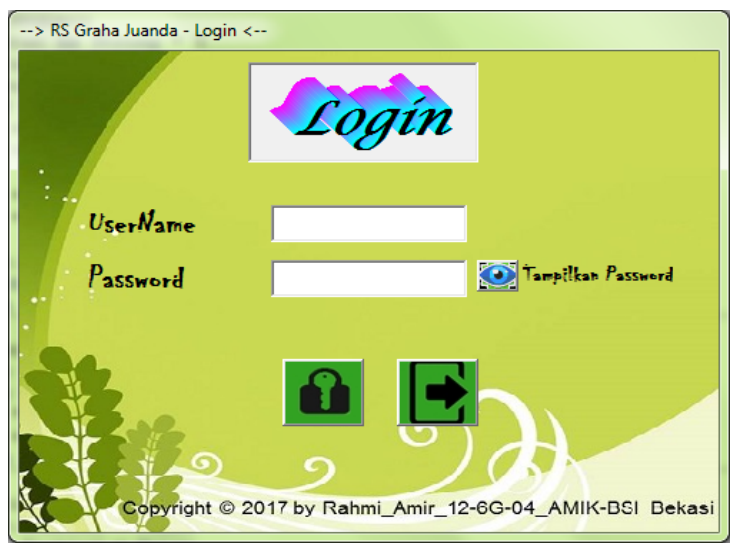

Gambar 6. Form Menu Login

b. Form Menu Utama

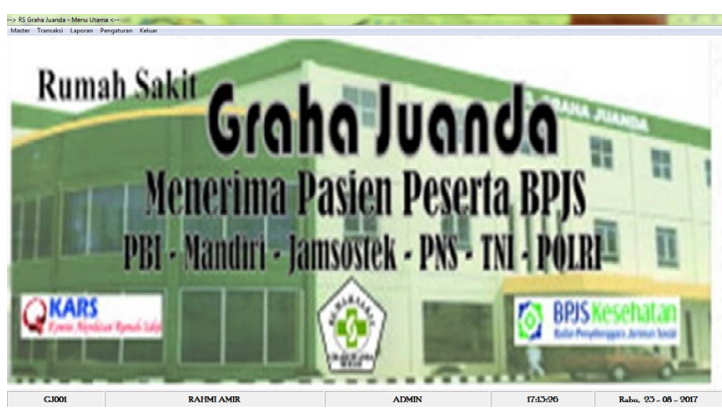

Gambar 7. Form Menu Utama

c. Form Menu Laporan

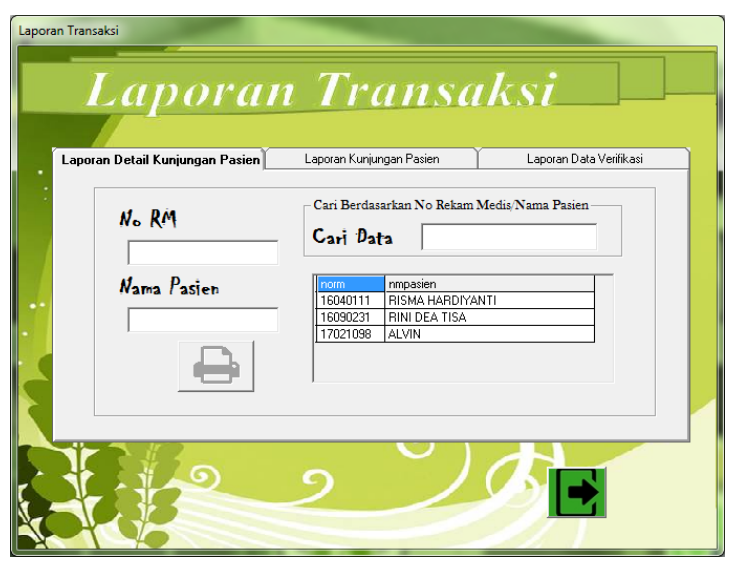

Gambar 8. Form Menu Laporan

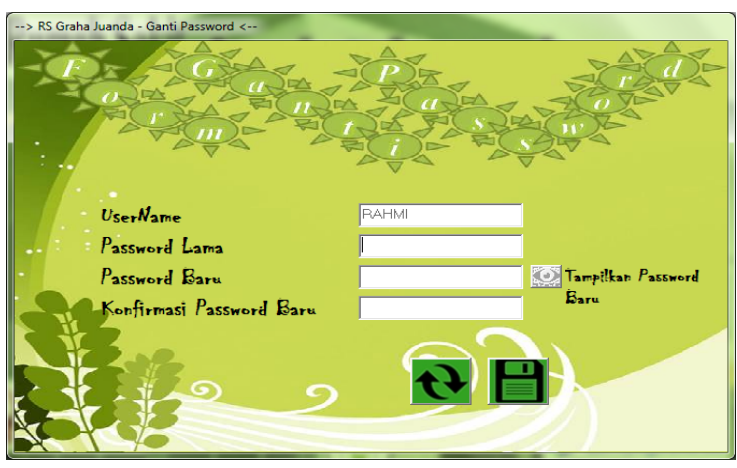

Gambar 9. Form Ganti Password

e. Form Laporan Kunjungan Pasien

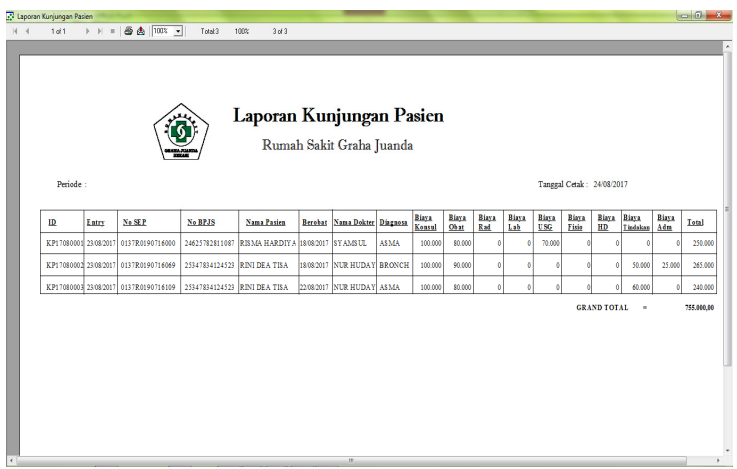

Gambar 10. Form Laporan Kunjungan Pasien

\section{f. Form Cetak Kwitansi}

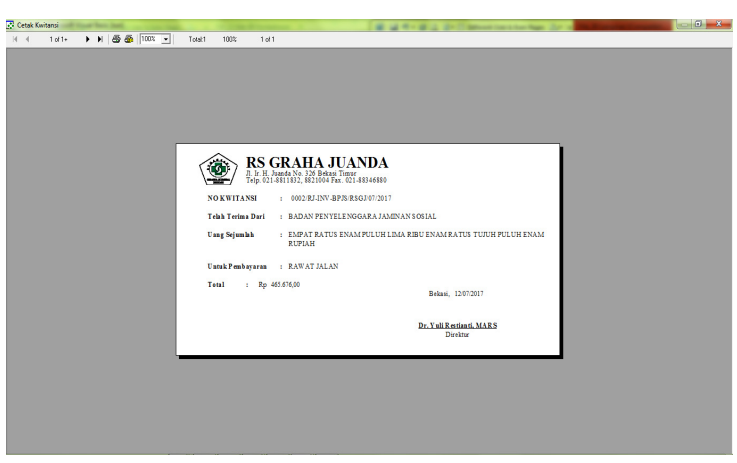

Gambar 11. Form Cetak Kwitansi

\subsection{Pengujian}

Sebelum aplikasi ini dapat digunakan oleh user, dilakukan terlebih dahulu pengecekan form yang dibuat dalam aplikasi ini dengan menggunakan blackbox testing untuk meminimalisir kesalahan.

\section{d. Form Ganti Password}


Tabel 9. Hasil Pengujian Black Box Testing Form Login User

\begin{tabular}{|c|c|c|c|c|c|}
\hline No & Skenario Pengujian & Test Case & Hasil Yang Diharapkan & $\begin{array}{c}\text { Hasil } \\
\text { Pengujian }\end{array}$ & Kesimpulan \\
\hline 2 & $\begin{array}{l}\text { Hanya mengisi User Name } \\
\text { dan mengosongkan data } \\
\text { Password, lalu langsung } \\
\text { mengklik tombol } \\
\text { " }\end{array}$ & $\begin{array}{l}\text { User Name: } \\
\text { (admin_rs) } \\
\text { Password: } \\
\text { (kosong) }\end{array}$ & $\begin{array}{l}\text { Sistem akan menolak akses } \\
\text { Login dan menampilkan } \\
\text { pesan "Password Harus Diisi } \\
\text { !" }\end{array}$ & $\begin{array}{l}\text { Sesuai } \\
\text { Harapan }\end{array}$ & Valid \\
\hline 3 & $\begin{array}{l}\text { Mengisi User Name dan } \\
\text { Password, lalu langsung } \\
\text { mengklik tombol } \\
\text { " }\end{array}$ & $\begin{array}{l}\text { User Name : } \\
\text { (admin_rs) } \\
\text { Password: } \\
\text { (1234567) }\end{array}$ & $\begin{array}{l}\text { Sistem menerima akses } \\
\text { Login dan menampilkan } \\
\text { pesan "Anda Login Sebagai } \\
\text { Administrator, Gunakan Hak } \\
\text { Akses Anda Dengan Benar !" }\end{array}$ & $\begin{array}{l}\text { Sesuai } \\
\text { Harapan }\end{array}$ & Valid \\
\hline
\end{tabular}

3.4. Pendukung (support) atau pemeliharaan (maintenance)

Pendukung aplikasi pembangunan sistem ini tidak terlepas dari perangkat Hardware dan

Software.

a. Spesifikasi Hardware

Hardware atau perangkat keras adalah suatu perangkat alat atau elemen elektronik yang dapat membantu sistem yang diusulkan agar berjalan dengan baik. Perangkat keras yang dibutuhkan ada dua yaitu perangkat keras untuk server dan perangkat keras untuk client. Spesifikasi perangkat keras minimal yang diperlukan untuk server adalah sebagai berikut:

$\begin{array}{ll}\text { Processor } & : \text { Celeron Dual Core } \\ 1,8 G h z & \\ \text { Memory Size (RAM) } & : 1 G B(D D R A M) \\ \text { Monitor } & : \text { LCD 14" } \\ \text { Harddisk } & : 240 \mathrm{~GB} \\ \text { Keyboard } & : 107 \text { Keys } \\ \text { Mouse } & : \text { Optical Mouse } \\ \text { Printer } & : \text { Deskjet }\end{array}$

Spesifikasi perangkat keras minimal yang diperlukan untuk client adalah sebagai berikut:

Processor : Celeron Dual Core

$1,8 \mathrm{Ghz}$

Memory Size (RAM)

Monitor

: 1GB (DDRAM)

Harddisk

: $\angle C D 14$

: $240 \mathrm{~GB}$

Keyboard

: 107 Keys

Mouse

: Optical Mouse

Printer

: Deskjet

\section{b. Spesifikasi Software}

Software atau perangkat lunak adalah suatu rangkaian atau susunan instruksi yang benar dengan urutan-urutan yang benar pula. Perangkat lunak yang dibutuhkan ada dua yaitu perangkat lunak untuk server dan perangkat lunak untuk client. Spesifikasi perangkat lunak minimal yang dibutuhkan oleh server dan client sebagai berikut:

Sistem Operasi : Windows 7 Ultimate

Bahasa Program : Visual Basic 6.0

Database Server : : MySQL

Pendukung : Crystal Reports

\section{KESIMPULAN DAN SARAN}

\subsection{Kesimpulan}

Program ini dapat membantu dan mempermudah proses pengelolaan data keuangan pasien rawat jalan BPJS, mulai dari proses input data sampai proses pembuatan laporan, sehingga dapat menghemat waktu, tenaga dan biaya, penyimpanan data dengan menggunakan media komputer lebih aman dari segi fisik maupun isi, sehingga proses pencarian data menjadi lebih cepat, mudah dan dapat mengurangi tingkat kesalahan, terhindar dari kerangkapan data karena kode yang diinput memiliki karakteristik tersendiri dan program ini juga dilengkapi dengan fasilitas backup database secara otomatis saat keluar dari program, sehingga sangat membantu Rumah Sakit dalam mengelola data dengan baik secara berkelanjutan. Penggunaan metode pengembangan sistem dengan metode pemodelan SDLC (System Development Life Cycle) yaitu Model Waterfall membantu mengarahkan langka-langkah apa saja yang dilakukan sehingga terselesaikannya program pengelolaan data keuangan pasien rawat jalan BPJS pada Rumah Sakit Graha Juanda Bekasi.

\subsection{Saran}

Kesalahan dalam pengelolaan data dapat menghasilkan data yang tidak akurat, oleh karena itu diperlukan pelatihan khusus untuk pemakai program agar meminimalisir terjadinya kesalahan dalam menjalankan program ini, perawatan dan pemeliharaan hardware dan software komputer sangat diperlukan agar sistem terhindar dari kerusakan, pada waktu tertentu lakukan pengecekan kembali terhadap sistem, apabila terjadi perubahan kebutuhan program, maka untuk dapat menyediakan informasi yang aktual perlu diadakan lagi tahap-tahap pembuatan program dan komputer sebaiknya dilengkapi dengan software anti virus, untuk mengantisipasi adanya serangan virus yang dapat menyebabkan kerusakan data. 


\section{DAFTAR PUSTAKA}

Abdul, K. (2012). Algoritma dan pemrograman menggunakan java. Yogyakarta: Andi Offset

Arini, L., Sulindawati, N. L. G. E., SE Ak, M., Herawati, N. T., \& AK, S. (2015). ANALISIS PENGENDALIAN INTERN TERHADAP PERSEDIAAN OBAT UNTUK PASIEN PENGGUNA BPJS (BADAN PENYELENGGARA JAMINAN SOSIAL) KESEHATAN DI RSUD (RUMAH SAKIT UMUM DAERAH) KABUPATEN BULELENG. JIMAT (Jurnal IImiah Mahasiswa Akuntansi S1), 3(1).

Handoko, B. (2010). Seri Panduan Pemrograman Database Visual Basic 6.0 dengan Crystal Reports. Yogyakarta: Andi Publiser.

Jogiyanto, H. M. (2005). Analisis dan desain sistem informasi. Yogyakarta: Andi Offset.

Lubis, B. O. (2016). PENERAPAN GLOBAL EXTREME PROGRAMMING PADA SISTEM INFORMASI WORKSHOP, SEMINAR DAN PELATIHAN DI LEMBAGA EDUKASI. Jurnal Informatika, 3(2).

Mardi, D., \& Si, M. (2011). Sistem Informasi Akuntansi.

Rahmayu, M. (2015). RANCANG BANGUN SISTEM INFORMASI NILAI UJIAN SISWA SMP NEGERI 3 BUMIAYU BERBASIS WEB. Jurnal Khatulistiwa Informatika, 3(2).

Rosa, A. S., \& Shalahuddin, M. (2013). Rekayasa perangkat lunak terstruktur dan berorientasi objek. Bandung: Informatika.

Shalahuddin, M. (2010). Pemrograman Berorientasi Objek dengan Bahasa Pemrograman $\mathrm{C}++$. PHP, dan java, Bandung: Modula.

Simarmata, J., \& Paryudi, I. (2006). Basis data. Yogyakarta: Penerbit Andi.

Swastika, W. (2008). VB \& MYSQL, PROYEK MEMBUAT PROGRAM GENERAL LEDGER SERI 1. DIAN RAKYAT: Jakarta.

Winarno, E. (2013). Belajar Pemrograman VB6 Dalam Sekejap. Jakarta: Elex Media Komputindo. 